\title{
Factors Affecting the Quality of University Lecturers - A Research Conducted Within the Context of Vietnam Society
}

\author{
Ngo Sy Trung", *, Ta Quang Tuan², Do Thi Thu Huyen ${ }^{3}$, Tran Thi Ngan $\mathrm{Ha}^{4}$, Ho Thi Mong Tuyen ${ }^{5}$, \\ Nguyen Thi To Loan ${ }^{6}$ \\ ${ }^{1}$ Institute of Research and Development on Home Affairs, Hanoi University of Home Affairs, Hanoi City, Vietnam \\ ${ }^{2}$ State Management Review, National Academy of Public Administration, Hanoi City, Vietnam \\ ${ }^{3}$ Faculty of Office Management, Hanoi University of Home Affairs, Hanoi City, Vietnam \\ ${ }^{4}$ Faculty of Human Resource Management, Hanoi University of Home Affairs, Hanoi City, Vietnam \\ ${ }^{5}$ Faculty of Human Resource and Society Management, Hanoi University of Home Affairs - Quang Nam Province Campus, Quang Nam \\ Province, Vietnam \\ ${ }^{6}$ International Cooperation Department, Hanoi University of Home Affairs, Hanoi City, Vietnam
}

\section{Email address:}

ngosytrung01@yahoo.com (N. Sy Trung)

*Corresponding author

\section{To cite this article:}

Ngo Sy Trung, Ta Quang Tuan, Do Thi Thu Huyen, Tran Thi Ngan Ha, Ho Thi Mong Tuyen, Nguyen Thi To Loan. Factors Affecting the Quality of University Lecturers - A Research Conducted Within the Context of Vietnam Society. Higher Education Research.

Vol. 6, No. 3, 2021, pp. 58-62. doi: 10.11648/j.her.20210603.11

Received: April 14, 2021; Accepted: May 10, 2021; Published: May 21, 2021

\begin{abstract}
There are many factors affecting the quality of faculty that numerous researchers mentioned, analyzed and pointed out the different degrees of influence. The paper studies external factors affecting the quality of faculty such as Political regime, Management mechanism and Salary regime. These three factors have been existing in each country and make a different impact on the quality of faculty creating the unique characteristics of each country. The author builds a theoretical framework for research on the above-mentioned three ones and conduct a direct survey of 400 lecturers from 10 universities in Hanoi - the capital city of Vietnam. The survey is selectively done, in which its surveyed subjects are lecturers with doctorate or higher and their working time from 5 years or more. Through secondary data collected from published documents combined with those gained from direct investigations and surveys, the author contributes to clarifying the impact of the abovementioned factors on the quality of Vietnamese faculty. From that result, he proposes a number of workable solutions on the policies with the hope of providing leaders and managers with scientific arguments so that they have more sound bases to appropriately adjust their policies to satisfy the essential needs of lecturers, which helps them have more opportunities to create and maximize their capacity. That also contributes to completing the policies on developing a team of high-quality Vietnamese faculty meeting the requirements of higher education in the modern and integrated social context.
\end{abstract}

Keywords: Lecturers, Quality of Faculty Members, Quality of Faculty

\section{Introduction}

In each country, faculty is considered as a special labor force directly training other human resources for society, so the quality of faculty is often attached special importance and subject to the rather high requirements. Vietnamese law clearly stipulates criteria for lecturers including such basic contents as ethical quality, professional qualifications and knowledge, scientific research capacity, and teaching capacity. The quality of faculty is affected by both subjective and objective factors, which are their proactive efforts in learning and training (subjective factors); working environment, professional characteristics, lecturer development policy, political regime, management mechanism, salary regime... (objective factors).

Each of the above-mentioned factors has different impacts on the quality of faculty; In each different country, some of them can be easily adjusted from while some are beyond the control of the lecturers themselves and higher education institutions. 
Those are factors regarding Politics; Management mechanism and Salary regime. However, these have their own characteristics consistent with the political regime and Vietnam state institutions. Therefore, studying those affecting the quality of faculty within the context of Vietnam society is essential.

\section{Literature Review}

The term 'lecturer' is understood as the professional title of those doing teaching and researching work in higher education institutions. This approach adopted by many researchers has determined that this is a special labor force directly training other human resources for the society. Hence, the quality of faculty has a great influence on the development of higher education institutions when it comes to their competitiveness and quality of products and services. In terms of research and management, the quality of lecturers is mentioned in such contents as Ethical qualities, Professional qualifications and knowledge, Scientific research capacity and Teaching capacity $[1,3,5,11,12]$. At the same time, it is affected by many factors including political regime, management mechanism and Salary regime [6-10, 14, 15]. In Vietnam, these factors have an impact on the quality of faculty as shown below:

\subsection{Political Regime}

The principle that the Party leads the State and the entire society is specified in the Constitution of the Socialist Republic of Vietnam [13]. Accordingly, all activities by State agencies, organizations and individuals are not contrary to Party's viewpoints, lines and strategies. Therefore, faculty's professional activities are dominated by political factors as follows:

1. IF1: Their academic creativity and freedom do not exceed the scope of the Party's viewpoints, lines and strategies.

2. IF2: Their creativity and development in professional teaching capacities do not exceed the scope of the Party's viewpoints, lines and strategies.

\subsection{Management Mechanism}

Vietnam's public higher education institutions are under general management mechanism, which means they are under governing state agencies' state management. The faculty members are subject to the principles prescribed by law $[3,11,12]$. For this reason, it is difficult to have a breakthrough in management to exploit and develop their professional capacities, namely:

1. IF3: The recruitment of intellectual lecturers often has its own mechanism under the proposition of the governing state agencies. In many cases, this causes higher education institutions to lose the opportunity to attract highly qualified people as lecturers.

2. IF4: The appointment and development of intellectual lecturers often have their own mechanism under the proposition of the governing state agencies. In many cases, this reduces working motivation and affects the faculty's teaching quality and efficiency.

\subsection{Salary Regime}

The faculty's working regimes are imposed under their professional titles and salary grades prescribed by law on public employees [2] but have not yet to apply according to their job positions in order to clearly define each lecturer's level of income. This factor affects their work motivation leading to impacts on their teaching quality and efficiency, namely:

1. IF5: Salary regime defined according to titles and salary grades leads to the dispersion of lecturers' capacities and the negligence of professional work at higher education institutions.

2. IF6: Salary regime defined according to titles and salary grades has yet to meet the lecturers' needs and capacities.

Research hypothesis

H1: The Party's viewpoints, lines and strategies affecting the faculty's academic creativity and freedom.

H2: The Party's viewpoints, lines and strategies affecting the faculty's creativity and development in professional teaching capacities.

H3: General management mechanism for public employees affecting recruitment of highly qualified faculty.

H4: General management mechanism for public employees affecting the appointment and development of highly qualified faculty.

H5: Salary regime by titles and salary grades affecting the faculty's dedication to their professional work.

H6: Salary regime by titles and salary grades affecting the satisfaction with the faculty's needs and capacities.

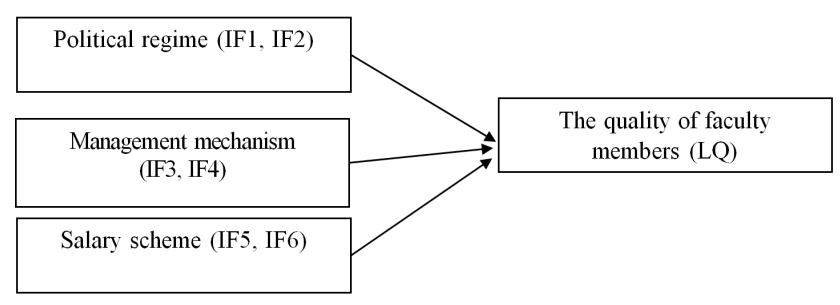

Figure 1. Research models.

\section{Research Model and Hypothesis}

Through the literature review, 3 factors affecting the quality of faculty with 6 observed variables (including IF1, IF2, IF3, IF4, IF5, IF6) have been determined. Therefrom, the author has been put forward research model and hypothesis as shown below:

\section{Research Methodology}

The secondary data were collected and analysed from published documents combined with those gained from direct surveys. For the primary data, the author conducted two steps including Preliminary and official surveys. 


\subsection{Preliminary Survey}

The survey was designed based on research models and hypotheses with demographic information (including gender, age, education level, income, number of teaching years) and 6 observed variables as mentioned in the literature review. These variables were measured in the 5-point Likert scales: 1 - Strongly disagree; 2 - Disagree; 3 - Neither disagree nor agree; 4 - Agree; 5 - Strongly agree. A preliminary survey of 100 lecturers was conducted and its findings show that the observed variables are reliable to be used in the official survey.

\subsection{Official Survey}

A survey of 400 lecturers from 10 universities in the area of Hanoi Capital where most of universities in Vietnam are located were conducted in 2020. They all have doctorates or higher degrees and their working time is 05 years or more.

The questionnaires were sent directly to the lecturers using the method of non-random sampling (preliminary interview to know the qualifications, number of teaching years and their consent to answer the questionaires). The result obtained is that $400 / 400$ questionnaires are satisfactory with the response rate of $100 \%$.

Table 1. Descriptive statistics of the study samples.

\begin{tabular}{|c|c|c|c|}
\hline Variables & Group classification & Frequency & Rate \\
\hline \multirow{2}{*}{ Gender } & Males & 282 & $70,5 \%$ \\
\hline & Females & 118 & $29,5 \%$ \\
\hline \multirow{3}{*}{ Academic ranks } & Doctorates & 310 & $77,5 \%$ \\
\hline & Associate Professors & 81 & $20 \%$ \\
\hline & Professors & 9 & $2,5 \%$ \\
\hline \multirow{2}{*}{ Working time at university } & $5-10$ years & 64 & $16 \%$ \\
\hline & 10 years and over & 336 & $84 \%$ \\
\hline \multirow[t]{2}{*}{ Monthly salary range } & 15-20 million VND & 87 & $21,5 \%$ \\
\hline & More than 20 million VND & 138 & $34,5 \%$ \\
\hline
\end{tabular}

Source: The author's survey findings in 2020

Table 2. Findings of testing the scale reliability.

\begin{tabular}{lll}
\hline Variables & Cronbach's Alpha & The correlation coefficient of the smallest total variables \\
\hline IF1: Political regime 1 & 0,613 & 0,322 \\
IF2: Political regime 2 & 0,741 & 0,319 \\
IF3: Management mechanism 1 & 0,788 & 0,602 \\
IF4: Management mechanism 2 & 0,832 & 0,554 \\
IF5: Salary regime 1 & 0,814 & 0,568 \\
IF6: Salary regime 2 & 0,825 & 0,521 \\
LQ: The quality of faculty & 0,657 & 0,308 \\
\hline
\end{tabular}

Source: The author's survey findings in 2020

Table 3. Findings from regression analysis.

\begin{tabular}{|c|c|c|c|c|c|}
\hline \multirow{2}{*}{ Variables } & \multirow{2}{*}{ Regression coefficients (B) } & \multirow{2}{*}{ Beta Coefficients } & \multirow{2}{*}{ Significance } & \multicolumn{2}{|c|}{ Multi-collinear statistics } \\
\hline & & & & Tolerance & VIF \\
\hline Constants & 1.307 & & .000 & & \\
\hline IF3: Management mechanism 1 & .127 & .289 & .000 & .738 & 1.359 \\
\hline IF5: Salary regime 1 & .112 & .217 & .000 & .711 & 1.403 \\
\hline IF6: Salary regime 2 & .185 & .303 & .000 & .714 & 1.392 \\
\hline IF2: Political regime 2 & .196 & .315 & .000 & .674 & 1.479 \\
\hline IF4: Management mechanism 2 & .121 & .260 & .000 & .713 & 1.402 \\
\hline IF1: Political regime 1 & .122 & .278 & .000 & .863 & 1.154 \\
\hline \multicolumn{6}{|l|}{ LQ: The quality of faculty } \\
\hline R2 Adjustment: 0,355 & & & & & \\
\hline
\end{tabular}

Source: The author's survey findings in 2020

\section{Research Findings}

\subsection{Statistics of Study Samples}

Descriptive statistics of the study samples in Table 1 show that number of males accounts for $70.5 \%$ and females $29.5 \%$; doctorates accounts for $77.5 \%$, associate professor $20 \%$ and professor $2.5 \%$; teaching time at universities of 5-10 years accounts for $16 \%$, over 10 years $84 \%$; the monthly salary below 15 million VND accounts for $44 \%$, from $15-20$ million VND $21.5 \%^{1}$ and over 20 million VND $34.5 \%{ }^{2}$.

1 This salary range is less than 1000 USD

2 This salary range is about 1000 USD or more. 


\subsection{Findings of Testing the Scale Reliability}

The testing findings show that Cronbach's Alpha coefficients of total variables are greater than 0.6 and total variable correlation coefficients are greater than 0.3 , so these variables continue to be used in exploratory factor analysis EFA [4].

\subsection{Findings of Exploratory Factor Analfigysis (EFA)}

The findings of testing the scale of measurement for the independent variables show that $\mathrm{sig}=0.000, \mathrm{KMO}=0.814$ ( $>$ $0.5)$. EFA findings after two tests show that by using factor extraction method Principal Component and the varimax rotation, 6 factors were extracted with cumulative variance of $64.5 \%(>50 \%)$, Eigenvalue value ranging from 1.243 to $7.296(>1)$ and the factor load coefficients of the observed variables greater than 0.5 . So, it can be concluded that the scale of measurement meets the requirements.

The testing findings of above-mentioned Cronbach's Alpha and EFA show that the scales of measuremen for both independent and dependent variables meet the requirements for value and reliability, and they will be included in the next quantitative research.

\subsection{Findings from Regression Analysis}

The findings of regression analysis in Table 3 show that the relationship between the dependent and independent variables is of statistical significance (Sig. <0.05). R2 Adjustment $=0.355$ shows that $35.5 \%$ of the variation of the dependent variables is explained by the independent ones. The value of VIF coefficients of all variables is lower than 10, proving that the multicollinearity phenomenon does not occur. Independent variables (IF1, IF2, IF3, IF4, IF5, IF6) with B coefficients are of positive with Sig. $<0.05$, so the hypotheses H1, H2, H3, H4, H5, $\mathrm{H} 6$ are accepted. It is shown in the following regression equation:

$$
\begin{gathered}
\mathrm{Y}=1.307+0.112 * \mathrm{X} 1+0.121 * \mathrm{X} 2+0.122 * \mathrm{X} 3+0.127 * \mathrm{X} 4+ \\
0.185 * \mathrm{X} 5+0.196 * \mathrm{X} 6
\end{gathered}
$$

The regression coefficients all bear positive signs $(+)$, representing that the independent variables are positively related to the dependent ones. The impacts of the 06 independent variables (IF1, IF2, IF3, IF4, IF5, IF6) on the dependent ones (LQ) are in a descending order as follows: IF2 (Political regime 2), IF6 (Salary regime 2), IF3 (Management mechanism 1), IF1 (Political regime 1), IF4 (Management mechanism 2), IF5 (Salary regime 1).

\section{Conclusion}

The research findings confirm that external factors have an impact on the quality of faculty in a gradually decreasing degree within the context of Vietnam society, which are IF2 (Political regime 2), IF6 (Salary regime 2), IF3 (Management mechanism 1), IF1 (Political regime 1), IF4 (Management mechanism 2), IF5 (Salary regime 1). From the study findings, some suggestions on governance have been proposed as follows:

1. Firstly, the characteristics of the political regime (the Party's viewpoints, lines and strategies) have a great impact on the faculty's academic freedom, teaching capacity development and academic creativity. Therefore, it is necessary to ensure relative independence between the faculty's academic freedom and professional capacity development with the Party's viewpoints, lines and strategies.

2. Secondly, the management mechanism (the lecturers are managed under general principles for public employees) has quite a clear influence on the faculty's professional capacity development and academic creativity. Therefore, the assignment of the autonomous mechanism for developing teaching human resources for higher education institutions should be done thoroughly so as that every higher education institution proactively maintains and develops its intelectual faculty to meet the development requirements in the present and future.

3. Thirdly, the salary regime (salary system according to titles and salary grades applicable to public employees) significantly affects the faculty's satisfaction and working motivation. Therefore, it is very important to have a distinct salary regime suitable to their intellectual labor so that they can focus on their expertise and academic creativity in order to improve the training quality of human resources for the society.

\section{References}

[1] Ministry of Education and Training, Ministry of Home Affairs (2014), Joint Circular No. 36/2014 / TTLT-BGDĐT-BNV dated November 28, 2014 providing codes and standards for professional titles of faculty members in public higher education institutions.

[2] The Government (2018), Decree No. 72/2018 / ND-CP dated May 15th, 2018 regulating the basic salary for cadres, civil servants, public employees and the armed forces' personnel.

[3] The Government (2019), Decree No. 99/2019 / ND-CP dated December 30, 2019 detailing and guiding the implementation of a number of articles of the Law amending and supplementing a number of articles of the Law on Higher Education.

[4] Do Huu Hai, Ho Sy Ngoc (2018), "Statistical probability and quantitative methods in economics", Hanoi Labor Publishing House.

[5] Le Duong Thuy Huong (2020), "Enhangcing the efficiency of science rerearch activities in Vietnamese universities and college", Journal of Educational Management Science, No. 25 .

[6] Ngo Sy Trung (2018), “Additional discussion about professional standards for lecturers", Journal of Theoretical Education, No. 271. 
[7] Ngo Sy Trung, Tran Thanh Xuan (2021), "The quality of faculty at Hanoi University of Home Affairs", Publishing House: National University of Economics.

[8] Nguyen Thi Thu Huong (2012), "Developing the faculty members in universities", Journal of Science, Hanoi National University, No. 28.

[9] Nguyen Minh Duc (2013), "Improving lecturers' scientific research capacity to well perform the role of creating knowledge in universities", Monographs on Improving the quality of higher education, Publishing House: The Youth.

[10] Phan Hong Duong, Đang Thi Kim Dung, Luong Thi Quynh Ly (2020), "Build a quality assurance system inside the university", Journal of Education Management, No. 12.

[11] National Assembly (2010), Law on Public Employees No. 58/2010 / QH12 dated November 15, 2010 (amended and supplemented in 2019).
[12] National Assembly (2012), Law on Higher Education No. 08/2012 / QH13 dated June 18, 2012 (amended and supplemented in 2018).

[13] National Assembly (2013), Constitution of the Socialist Republic of Vietnam.

[14] Tran Mai Uoc (2013), "Scientific research activities by lecturers - An important factor contributing to improving the quality of training activities at universities in the current period", Journal of Political Theory and Media, No. August 2013.

[15] Tran Thanh Xuan (2020), "Analyzing the competencies of Hanoi University of Home affairs' lecturers via the scientific research competencies", Vietnam Trade and Industry Review, No. 23. 